\title{
Intrusi Air Laut Berdasarkan Resistiviti dan Hidrokimia di Pesisir Tugu Kota Semarang, Indonesia
}

\author{
Sugeng Widada ${ }^{1 *}$, Baskoro Rochaddi ${ }^{1}$, Chrisna Adhi Suryono2, dan Irwani2 \\ 'Departemen Oseanografi, Fakultas Perikanan dan IImuKelautan, Universitas Diponegoro \\ 2Departemen IImu Kelautan, Fakultas Perikanan dan IlmuKelautan, Universitas Diponegoro \\ Jl. Prof. Soedarto, SH. Tembalang, Semarang 50275 Indonesia
}

Email : sugeng widada@undip.ac.id

\begin{abstract}
Sea Water Intrusion Based on Resistivity and Hydrochemical in Tugu Coastal of Semarang, Indonesia

Tugu Coastal Area is one of the coastal areas in Semarang City, Central Java Province that continues to grow. Although the clean water network from the Local Water Supply Utility is available, groundwater is still used to meet the water needs of the community. Some of the groundwater in the area is brackish to salty conditions as the result of sea water intrusion process. The research aims to determine configuration of aquifers which have been intruded with sea water in Tugu Coastal Area, Semarang City, so that groundwater exploitation from the aquifer can be avoided. The method used in this study was descriptive analysis, in which the condition of aquifers was based on interpretation of resistivity data. Simple hydrochemical facies analysis using the Trilinier Piper Diagram method is carried out to detect sea water intrusion. The results of the study indicated that aquifers in the Coastal area consisted of several layers. Aquifer which has been intruded with seawater is located on the north side of the Semarang - Kendal highway, both for confined and unconfined aquifers. The depth of confined aquifer which is intruded by sea water reaches $50-75 \mathrm{~m}$ below the local land surface. While the unconfined aquifer depth is up to a depth of $6 \mathrm{~m}$ below the local land surface.
\end{abstract}

Keywords : trilinier piper; resistivity; seawater intrusion; aquifer

\begin{abstract}
Abstrak
Wilayah Pesisir Tugu, Kota Semarang, Provinsi Jawa Tengah merupakan salah satu daerah pesisir di Kota Semarang yang terus berkembang. Meskipun jaringan air bersih dari Perusahaan Daerah Air Minum telah tersedia, namun pemanfaatan air tanah masih digunakan untuk memenuhi kebutuhan air bagi masyarakat. Sebagian air tanah di daerah tersebut dalam kondisi payau hingga asin yang diduga akibat proses intrusi air laut.. Penelitian ini bertujuan untuk mengetahui konfigurasi akuifer yang telah terintrusi air laut Wilayah Pesisir Tugu, Kota Semarang, sehingga dapat dihindari pengambilan air tanah dari akuifer tersebut. Metode penelitian yang digunakan dalam penelitian ini adalah diskriptis analisis untuk menggambarkan kondisi akuifer berdasarkan hasil interpretasi data geolistrik resistiviti. Analisa fasies hidrokimia secara sederhana dengan metode Diagram Triliner Piper dilakukan untuk mendeteksi adanya intrusi air laut. Hasil penelitian menujukan bahwa akuifer di daerah Pesisir Tugu terdiri dari beberapa lapisan. Akuifer yang telah terintrusi air laut adalah yang berada di sebelah utara jalan raya Semarang - Kendal, baik untuk akuier bebas maupun akuifer tertekan. Kedalaman akuifer tertekan yang terintrusi adalah hingga mencapai 50 sampai dengan $75 \mathrm{~m}$ di bawah muka tanah setempat. Sedangkan kedalaman akuifer bebasnya berada hingga kedalaman $6 \mathrm{~m}$ di bawah muka tanah setempat
\end{abstract}

Kata kunci : trilinier piper; resistiviti; intrusi air laut; akuifer 


\section{PENDAHULUAN}

Sebagai kota yang terus berkembang, dari waktu kewaktu pertumbuhan industri, pemukiman, perdagangan dan jasa di Kota Semarang semakinmeningkat. Sejalan dengan hal tersebut, maka kebutuhan air bersih juga mengalami peningkatan, baik digunakan untuk memenuhi kebutuhan hidup sehari-hari penduduk maupun untuk proses produksi dan kegiatan di sektor industri serta jasa. Di daerah tersebut, air tanah merupakan salah satu sumber air bersih yang banyak digunakan, karena mudah diperoleh dan relative murah eksplorasi dan eksolitasinya. Sayangnya beberapa akuifer, terutama di daerah pesisir Kota Semarang telah terjadi percampuran air tanah dengan air laut sehingga tidak layak dijadikan sebagai sumber air bersih tanpa pengolahan terlebih dahulu.

Keberadaan air tanah di Kota Semarang telah di selidiki oleh Direktorat Geologi Tata Lingkungan. pada tahun 1997. Dari hasil penelitian ini didapatkan bahwa kualitas air tanah tertekan khususnya di dataran pantai pada daerah penyebaran kelompok akuifer Delta Garang umumnya baik dengan DHL kurang dari $1500 \mu \mathrm{S} / \mathrm{cm}$. Air tanah payau dijumpai di daerah simpang Lima, Jalan Pemuda, dan Tawang dengan nilai DHL mencapai $2100 \mu \mathrm{S} / \mathrm{cm}$ (Arifin, 1998). Akibat ekploitasi air tanah pada cekungan tersebut yang meningkat dari tahun ketahun, maka mengakibatkan terjadinya intrusi air laut (Nisa et al., 2012). Di sisi lain Abidin, et al. (2010 dan 2013) meyatakan bahwa Kota Semarang bawah tersusun oleh endapan Delta Garang yang berupa lempung, lanau, pasir dan kerikil, baik berlapis maupun membentuk lensa. Endapan delta yang demikian sangat memungkinkan terjadinya air laut yang terjebak selama proses sedimentasi, sehingga air tanah pada sedimen yang bersangkutan asin secara bawaan atau dikenal sebagai connate water. Dengan demikian keasinan air tanah dapat terjadi sebagai akibat intrusi air laut ke dalam sistem akuifer atau air tanah asin yang bersangkutan adalah sebagai connate water. Secara keseluruhan, para peneliti terdahulu sebagaiman disebutkan di atas sependapat bahwa di Kota Semarang telah terjadi intrusi air laut kedalam akuifer. Namun demikian belum dinyatakan secara lebih jelas, sebaran akuifer yang terintrusi tersebut. Oleh karena itu, penelitian ini dilakukan untuk menjawab tentang gambaran konfigurasi akuifer yang telah terintrusi air laut, yang pada penelitian sebelumnya belum dikemukakan.

Daerah Pesisir Kecamatan Tugu, di Kota Semarang bagian barat juga mempunyai air tanah yang asin pada beberapa titik, namun pada lokasi dan kedalaman yang berbeda, keasinan air tanah juga berbeda. Berkaitan dengan hal tersebut maka dilakukan penelitian ini yang bertujuan untuk mengetahui konfigurasi akuifer yang mengandung air asin dan untuk mengetahui penyebab kejadian keasinan air tanah tersebut berdasarkan analisa fasies hidrokimia air tanah yang bersangkutan.

\section{MATERI DAN METODE}

Dalam penelitian ini, konfigurasi akuifer diperoleh dari interpretasi data hasil pengukuran metode geolistrik resistiviti. Pada pelaksanaannya di lapangan, pengukuran resistiviti dilakukan dengan menggunakan konfigurasi elektrode Schlumberger sebagaimana yang sudah dilakukan oleh Nisa et al. (2012) dan Widada et al. (2017). Pada penelitian ini dilakukan pengukuran geolistrik sebanyak 4 titik sounding sebagaimana terlihat pada Gambar 1. Hasil interpretasi setiap titik pengukuran adalah berupa ketebalan berbagai lapisan litologi dan nilai resistivitinya. Korelasi kesamaan nilai resistiviti menghasilkan penampang lapisan litologi pada jalur pengukuran geolistrik tersebut, sehingga dapat diinterpertasikan pola konfigurasi akuifernya.

Untuk memastikan kebenaran interpretasi dan mengetahui penyebab keasinan air tanah pada akuifer tersebut, maka dilakukananalisa fasies hidrokimia dengan motode Diagram Tri Linear Paper sebagaimana yang telah dilakukan oleh Sihwanto (1991) dan Widada (2007). Pada metode Diagram Trilinier Piper ini, prosentase kandungan anion dan kation dari berbagai stasiun digambarkan dalam satu diagram (Gambar 2). Pembagian fasies untuk kation 
meliputi tipe Magnesium (Mg), tipe Sodium $(\mathrm{Na}+\mathrm{K})$, dan tipe Calsium (Ca). Sedangkan fasies untuk anion meliputi tipe Sulfat (SO 4 ), tipe Bicarbonat (CO $3+\mathrm{HCO} 3$ ), dan tipe Khlorida (Cl). Melalui diagram tersebut maka dapat digambarkan adanya percampuran dua jenis air yang berbeda sumbernya. Percampuran dua macam air yang berbeda sumbernya akan tergambar pada garis lurus yang menghubungkan dua titik yaitu titik air tawar dan titik air laut, sehingga dapat mendeteksi adanya intrusi air laut

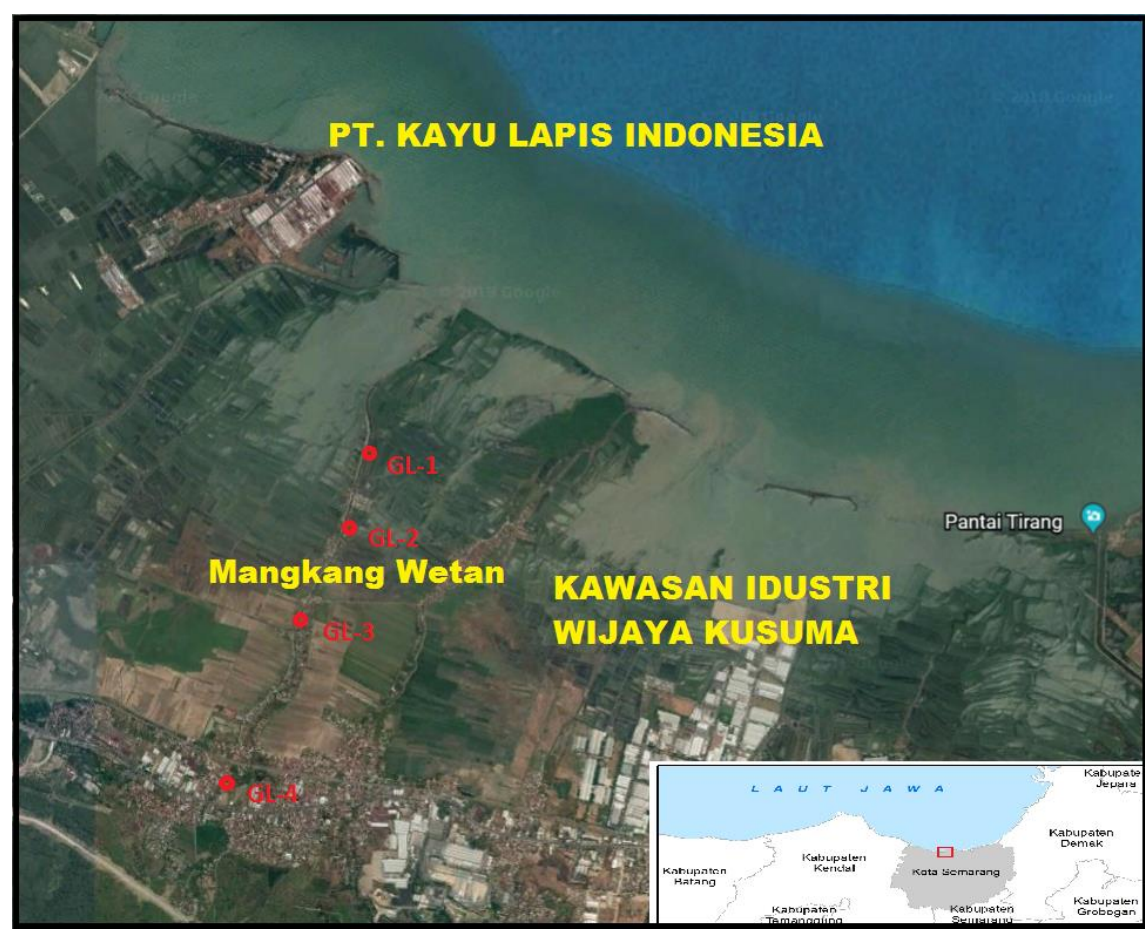

Gambar 1. Peta Lokasi Pengukuran Geolistrik

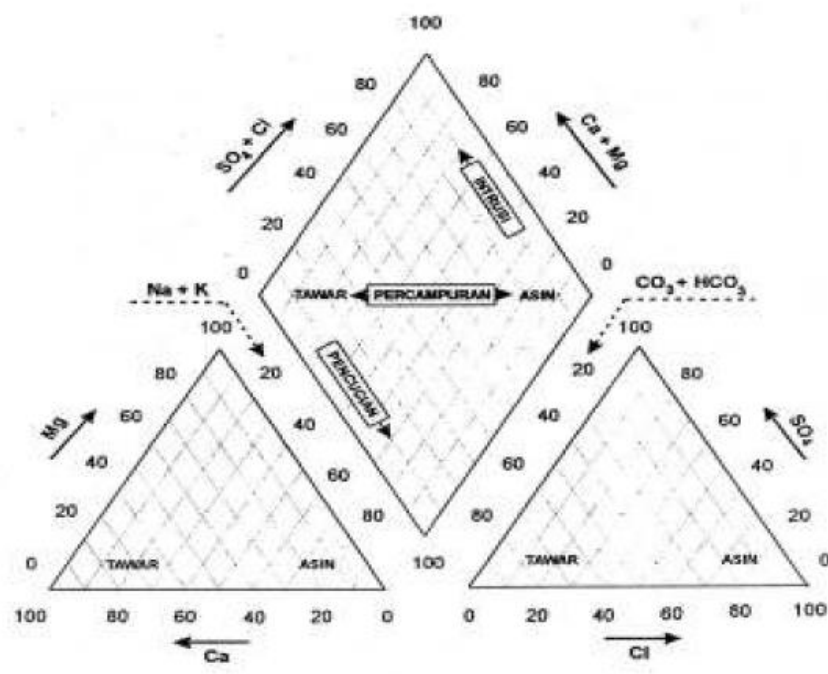

CATIONS

ANIONS

Gambar 2. Skema diagram Trilinier Paper (Mandel dan Shiftan, 1981) 


\section{HASIL DAN PEMBAHASAN}

Hasil pengukuran geolistrik resistiviti di daerah penelitian yang dibuat penampang litologi beserta interpretasinya terlihat seperti pada Gambar 3. Berdasarkan gambar tersebut terlihat bahwa secara stratigrafi lapisan terbawah di daerah penelitian adalah batupasir dengan nilai resistiviti 12 $18 \mathrm{ohm}$. Secara regional litologi ini diduga merupakan bagian dari batupasir Formasi Damar yang merupakan batuan dasar bagi endapan Delta Garang. Lapisan ini merupakan akuifer tertekan yang produktif dengan kualitas air tanahnya baik. Lapisan di atasnya berupa pasir dengan kandungan kerikil yang memepunyai nilai resistiviti $24-57$ ohm dan merupakan bagian dari endapan delta serta mengandung air tawar. Lapisan ini menjari dengan lapisan lanau yang diduga mengandung air payau yang diindikasikan dengan nilai resistivitinya yang rendah yaitu 3 - 6 ohm. Secara spasial, posisi lapisan lanau ini di sebelah utara lapisan pasir, sehingga lebih dekat kelaut. Hal ini memungkinkan terjadinya kontak antara air tanah pada lapisan lanau dengan air laut, namun tidak sampai kontak dengan air tanah pada lapisan pasir. Intrusi air laut hanya sampai pada lapisan lanau.

Lapisan yang mengandung air tanah bebas adalah litologi lanau dengan reistiviti sangat kecil yaitu 1,5 ohm sehingga diinterpretasikan mengandung air asin. Hal ini sesuai dengan Widada, et al. (2017) dan
Setyawan, et al. (2018) bahwa keberadaan air asin pada batuan akan memperkecil nilai resistiviti batuan yang bersangkutan. $\mathrm{Di}$ samping itu juga sesuai dengan pendapat Wardhana, et al. (2017) bahwa resistiviti yang rendah dijumpai pada litologi lanau dan lempung. Sedangkan lapisan lanaupasiran yang menjari dan berada di sebelah selatannya mempunyai resistiviti 12 - 19 ohm, sehingga diduga mengandung air payau sampai dengantawar. Bagian yang mempunyai resisitivi 19 ohm adalah yang mengandung air tawar yaitu di bawah titik 03. Lapisan paling atas sebagaimana terlihat pada Gambar 3 adalah lapisan penutup yang berupa lempung, lanau dan pasir yang merupakan tanah urug, endapan alluvial dan endapan pasang surut.

Hasil pengukuran daya hantar listrik air tanahdari sumur gali di titik geolistrik GL-02 menunjukan nilai 1.600 umhos yang berarti dalamk ondisi payau sebagaimana klasifikasi yang dibuat oleh Panitia Ad Hoc Intrusi Air Asin Jakarta (1986) dalam Widada (2007). Sedangkan air tanah dari sumur bor di titik GL-02 dalam kondisi payau dengan nilai DHL 1630 umhos dan air tanah dari sumur bor di titik GL-04 mempunyai DHL 800 umhos yang berarti dalam kondisi tawar. Pengeplotaan kation - anion dalam diagram Trilinier Piper dari sampel air pada lokasi tersebut di atas adalah sebagaimana tercantum pada Gambar 4. Berdasarkan gambar tersebut, terlihat bahwa pengeplotan kation-anion sampel airtanah dari sumur bor di titik GL-02

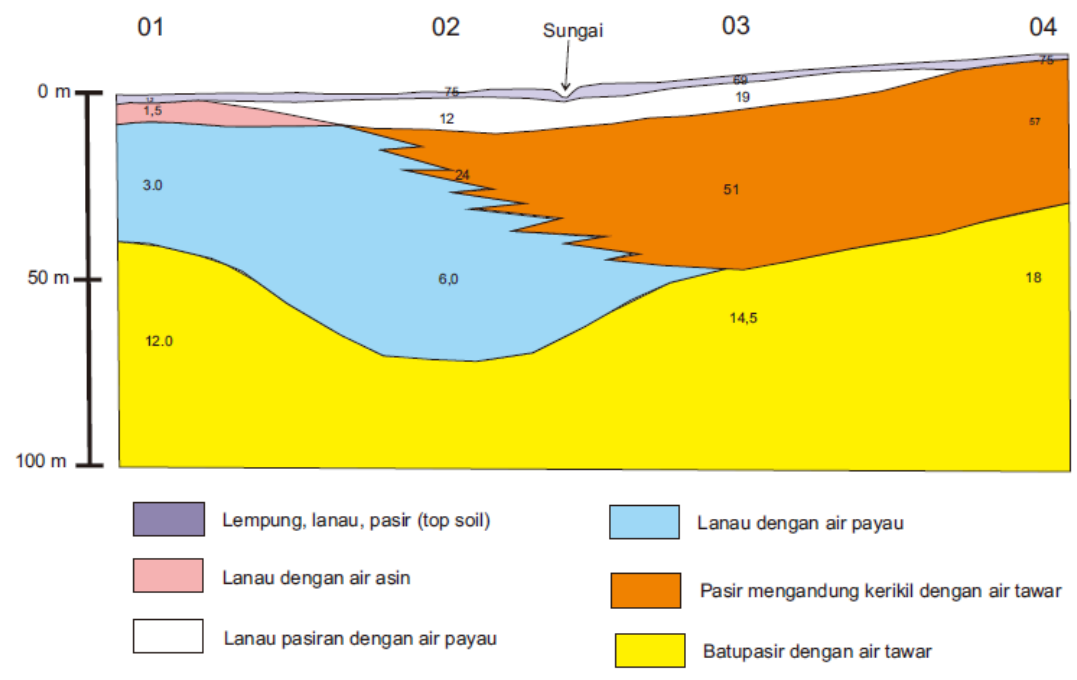

Gambar 3. Penamapang litologi berdasarkan interpretasi data resistiviti 


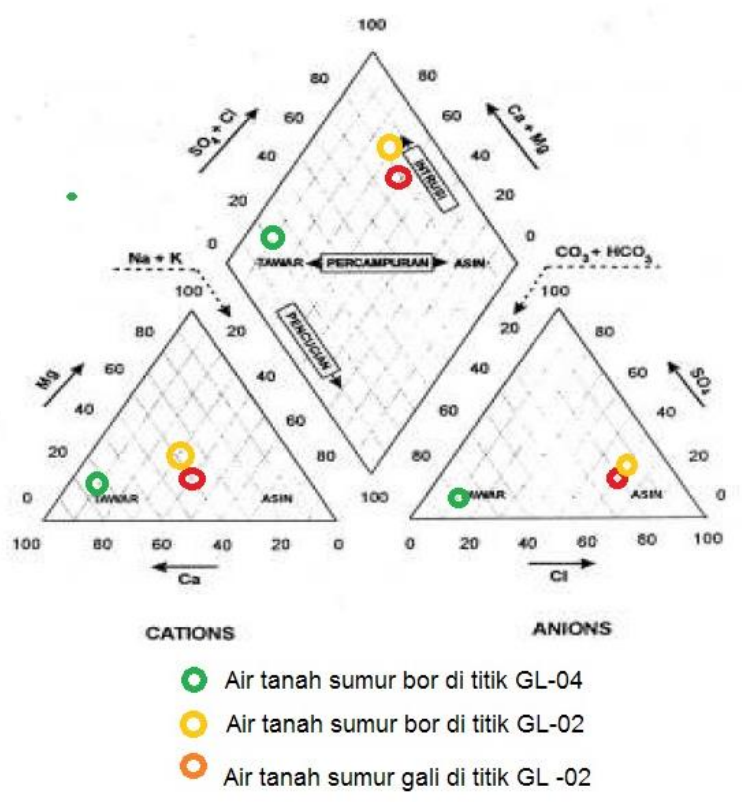

Gambar 4. Diagram Trilinier Piper pada beberapa contoh air tanah

dan sumur gali berada pada daerah air asin akibat intrusi air laut. Dengan demikian dapat disimpulkan bahwa air tanah pada akuifer bebas maupun akuifer tertekan di titik GL- 02 merupakan air asin yang disebabkan karena proses intrusi air laut. Kedalaman akuifer tertekan yang terintrusi adalah sekitar 50 meter sampai dengan 75 meter di bawah muka tanah setempat. Sedangkan kedalaman akuifer bebasnya berada hingga kedalaman 6 meter di bawah muka tanah setempat. Memperhatikan penampang akuifer sebagaimana tercantum pada Gambar 3, maka proses intrusi ini diduga melalui lapisan lanau yang kontak langsung dengan air laut secara langsung maupun akibat sering terjadinya banjir rob di wilayah pesisir. Hal ini sesuai dengan hasil pendapat Widada, et al. (2012) bahwa banjir rob di wilayah pesisir mempercepat proses intrusi air laut ke dalam akuifer bebas. Sedangkan air tanah pada sumur bor di titik GL-04 menunjukan air tawar yang belum terkontaminasi air laut. Hal ini membuktikan bahwa air tanah pada akuifer tertekan di titik GL-04 hingga kearah selatan belum terpengaruh oleh intrusi air laut.

\section{KESIMPULAN}

Akuiferter tekan di Daerah Pesisir Tugu Kota Semarang terdiri dari dua lapis, yaitu lapisan batu pasir dari Formasi Damar dan lapisan pasir kerikilan dari endapan delta. Air tanah pada kedua akuifer tersebut sepenuhnya dalam kondisi tawar. Lapisan lanau di bagian utara daerah penelitian juga mengandung air tanah tertekan namun dalam kondisi payau akibat intrusi. Sedangkan akuifer bebas dijumpai berupa lapisan lanau dengan air asin dan lanau pasiran dengan air payau. Intrusi air laut telah terjadi di daerah penelitian, baik pada akuifer bebas maupun pada akuifer tertekan, namun masih pada daerah yang berada di sebelah utara jalan raya Semarang - Kendal. Kedalaman akuifer tertekan yang terintrusi adalah sekitar 50 meter sampai dengan 75 meter di bawah muka tanah setempat. Sedangkan kedalam anakuifer bebasnya berada hingga kedalaman $6 \mathrm{~m}$ di bawah muka tanah setempat.

\section{DAFTAR PUSTAKA}

Abidin, H.Z., Andreas, H., Gumilar, I., Sidiq, T., Gamal, M., Murdohardono, D., Supriyadi \& Fukuda, Y. 2010. Studying Land Subsidence in Semarang (Indonesia) Using Geodetic Methods. Proceeding FIG Congress : 1-15

Abidin, H.Z., Andreas, H., Gumilar, I., Sidiq, T.P. \& Fukuda, Y. 2013. Land subsidence in coastal city of Semarang: 
characteristics, impacts and causes. Geomatics, Natural Hazards and Risk. 4(3):226 - 240

Arifin, B.M. \& Satrio, H. 1998, Penyelidikan Potensi Cekungan Air Tanah Semarang, Jawa Tengah, Laporan Penelitian, Direktorat Geologi Tata Lingkungan, Bandung. 86 hal.

Irham, M.N., Achmad, R.T., \& Widada, S. 2006. Pemetaan Sebaran Air Tanah Dalam Di Wilayah Asin pada Aquifer Semarang Bawah. Berkala Fisika. 9(3): 137 - 143

Mandel, S. \& Shiftan, Z.L. 1981. Groundwater Resources : Investigation And Development. Academic Press. London. 256 hal

Nisa, K. Yulianto, T. \& Widada, S. 2012. Aplikasi Metode Geolistrik Tahanan Jenis Untuk Menentukan Zona Intrusi Air Laut Di KecamatanGenuk Semarang. Berkala Fisika, 15(1):17-14

Setyawan, A., Najib, Yoga, A. \& Trihadini, A. 2016. Sea Water Intrusion in Kaligawe Semarang Based on Resistivity Data. IOP Conf. Series: Earth Environ. Sci. 55:012053

Sihwanto \& Satriyo. 1991. Metode Penentuan Penyebab Keasinan Air Tanah :Studi Kasus Daerah Dataran Pantai Dumai,
Riau. Kumpulan Makalah Ikatan Ahli Geologi Indonesia. Bandung. Hal 26402645.

Wardhana, R.R., Warnana, D.D. \& Widodo, A., 2017. Identifikasi Intrusi Air Laut Pada Air Tanah Menggunakan Metode Resistivitas 2D Studi Kasus Surabaya Timur. Jurnal Geosaintek. 03(01):17 - 22

Widada, S. 2007. Gejala Intrusi Air Laut di Daerah Pekalongan. Ilmu Kelautan: Ind. J. Mar. Sci. 12(1):45-52

Widada, S., Rochaddi, B., \& Endrawati, H, A. 2012. Pengaruh Arus Terhadap Genangan Rob di Kecamatan Sayung Kabupaten Demak. Bul. Oseano. Mar. 1: 31-39

Widada, S., Rochaddi, B., \& Satriadi, A. 2017. Kajian Potensi Air Tanah Berdasarkan Data Geolistrik Resistiviti Untuk Antisipasi Kekeringan di Wilayah Pesisir Kangkung, Kabupaten Kendal, Privinsi Jawa Tengah. Jur. Kel. Trop. 2(1):5-41

Widada, S. Saputro, S. \& Hariadi. 2018. Determination of Soft Lithology Causes The Land Subsidence in Coastal Semarang City by Resistivity Methods. IOP Conf. Series: Earth Environ.Sci. 116:012092 